\title{
Boucher de Perthes and the Foundations of Prehistoric Archæology
}

$\mathrm{P}$ REHISTORIC archæology, being one of the younger among the sciences, has had few opportunities of celebrating centenaries. It is a little more than a hundred years ago that the excavation of Kent's Cavern, Torquay (1825-29), first afforded a warrant for the tentative suggestion that man had lived in some remote past as a contemporary of an extinct mammalian fauna. Until this coexistence was demonstrated conclusively, discussion of the antiquity of man had no solid factual basis of inference on which to proceed. For this reason, Boucher de Perthes, on account of his discoveries of flint implements in the valley of the Somme, derived from geological horizons in which they were shown to be associated with the fossilized remains of extinct mammals, has been regarded as the founder of prehistory, and more especially of that branch of archæological studies which deals with the industries and cultures of the Old Stone Age.

It was in August 1837, according to his own record made not long afterwards, that Boucher de Perthes initiated his investigations of the geological deposits of the Somme valley for evidence of early man, and acquired the first objects in his collection. There is reason for thinking, however, that the correct date may have been in the following year. In fact, if Boucher de Perthes's statements be accepted, it is difficult to follow the course of events, or arrive at a just estimate of the credit to be assigned to him in the crucial discoveries in the later 'thirties and the 'forties of the last century.

In 1837, Boucher de Perthes was neither archæologist nor geologist. On his return to Abbeville from Paris in 1830, he was known only as an unsuccessful writer of satirical drama and a tendentious political economist, who had been expelled from the public service on account of his radical views; while up to 1841 he was immersed in the publication of a vast work entitled "La Création" on metaphysics, a subject in which, on his own showing, he had never read a word, and in which he relied not so much on his reason as his imagination. Writing in 1863, he claimed that so far back as 1805, when as a youth of seventeen he visited the Cave of Roland at Marseilles, and again in the Papal States in $\mathbf{1 8 1 0}$, the idea of discovering evidence of man as a contemporary of extinct mammals had been before him. But in making this claim, as well as others for an early dating of his views on the antiquity of man, his recollection was coloured by after events. These dates cannot be substantiated. His memory was highly imaginative, and he verified neither his recollections nor his dates.

Recent research in the early records of archæological studies in France has shown that prehistory, unlike Minerva, did not spring full-fledged from a single head. In Great Britain, the discovery of flint implements at Hoxne by John Frere in 1797 gave a lead ; similarly, in France from the early years of the nineteenth century, archæological discovery, as for example in the work of Jouannet in Perigueux, was pointing the way to the recognition of primitive phases in the development of civilization transcending by far the time limits then fixed by archæologist, palæontologist and geologist alike, whose vision for the time being was bounded by the views of Cuvier on the recent origin of man.

The apparent paradox of Boucher de Perthes's achievement as the founder of prehistory by his discoveries in the valley of the Somme, when contrasted with his character, attainments and previous history, has led M. Aufrère of the Institut de Géographie in the University of Paris* to examine not only his published works and correspondence, but also the drafts of his writings and letters with their numerous deletions, alterations and amendments, as well as the records of scientific activity at Abbeville at that period among those with whom Boucher de Perthes and his father before him were in touch. The result has been to throw an entirely new light on the course of events, and to give a new orientation in the investigations made by Boucher de Perthes, while meting out justice to the inspiration to which they were due.

The story begins with the foundation of the Société d'Emulation at Abbeville in 1795. Of the original members the most distinguished was Emmanuel Baillon, who had been of signal assistance to Buffon in his great work on natural history by his accurate observation of birds. Five years later, Cuvier was elected a member, and the announcement of his election was accompanied by a box of fossil bones of mammals found by the members in the neighbourhood of Abbeville. Cuvier's influence on the ideas and pursuits of the members of the society was considerable, especially in the domain of geology and palæontology. His view of the recent origin of man largely determined their attitude in discussing archæological material.

* Le Mouvement Scientifique à Abbeville dans la Première Moitié du XIX me Siecle et les Origines de la Préhistoire (1795-1840). Par L. Aufrère. Sciences, Assoc. Fr. pour l'Avmt. des Sciences. No. 4, 1936 Essai sur les Premières Découvertes de Boucher de Perthes et les Origines de l'Archeologie Primitive (1838-1844). Par L Aufrère. Expreuves et Synthèses, No. 1. (Paris. L. Staude, 1936.) Also other
papers. 
This accounts for the readiness of Boucher de Perthes and others to maintain, or, on occasion, revert to, the view that the stone implements discovered in the Somme deposits, like those found elsewhere, were 'Celtic'.

In the work of the fifty years which followed the foundation of the society, closing in 1844-45 with the presentation of the account by Boucher de Perthes of his discoveries, the achievement of certain of the members stands out. Of some of these only a brief mention must suffice.

The first in chronological order is Laurent Traullé (1758-1828), palæontologist and archæologist, wild in theory, but excellent in observation and discovery. It was he who supplied Cuvier with the fossil remains of elephant, rhinoceros, Bovidæ, horse and deer. He was the finder, in 1814, of a 'Celtic' hafted axe; but his most noteworthy contribution to archæology was the recorded observation of the stratified cultural sequence in the deposits of 'Celtic', Roman and 'Francisque' in this invariable order-an observation pregnant for archæology, albeit unfortunately forgotten until revived more than twenty years later. Most important of all, however, was his account of the stratification of the geological deposits of the Somme valley, the first of its kind.

Of those who were working at Abbeville in the years preceding Boucher de Perthes's investigations, two names to be noted are those of Alfred Tillette de Mautort and Dr. F. P. Ravin (17951849) ; both careful observers of geological evidence, whose detailed accounts of stratification in recording archæological finds brought archæology and geology into intimate relation. Dr. Ravin's authoritative records of geological formations were later to prove of much value to Boucher de Perthes, who made use of his specialized knowledge to support and authenticate his own observations.

The full implication of the relation between geology and archæology in the work of Ravin and de Mautort was developed by Casimir Picard, a name that has been forgotten, but deserving a better fate as that of an outstanding personality in the scientific, and more especially the archæological, activities of the Abbevillians between 1830 and 1840. Picard was born at Amiens in 1806, and went to Abbeville from Paris as a qualified medical man in 1828. Widely interested in scientific pursuits, but especially botany, palæontology and geology, he had unbounded energy, and on attaining office in the Société d'Emulation rapidly spurred that body to strenuous activity. He was associated with Boucher de Perthes in the organization of the Abbeville Museum, an association which, as M. Aufrère suggests, may have been responsible for the foundation of prehistory. His powers of lucid and cogent archæological argument were far in advance of his time, and would stand the test of modern application. In fact, his contributions to archæological theory went far to lay the foundation of archæology as a science. Of these, the more important were the rehabilitation of the flaked implement as something more than an unfinished stage, or a reject in the manufacture of a polished implement, as was then held; the demonstration of the relation of core, or nucleus, and flake as correlatives in the technique of flint fracture; and the argument from stratification for the contemporaneous character of deposits and con. tained artefacts, and hence the inferred coexistence of man and extinct fauna as contemporaries.

In May 1838, Picard presented a preliminary sketch of a report on the antiquities of Abbeville to be prepared in response to an official request. From this it appears probable that he had in mind a project for a series of excavations and investigations in the neighbourhood of Abbeville. Unfortunately, pressure of other interests, such as the foundation of the Linnean Society of Northern France in 1838, drew him away; and three years later, in March 1841, he died at the early age of thirty-four years. Had his life been prolonged, there can be no doubt that the early history of prehistoric discovery in the Somme valley would have been far different. His precision and appreciation of scientific method would have averted the ineptitudes which delayed the acceptance of Boucher de Perthes's very considerable contribution to the advancement of knowledge.

Picard's archæological insight and his enthusiasm, however, were not to be without effect. On more than one occasion Boucher de Perthes recorded that his investigations, whether beginning in 1837 or in 1838 , were first undertaken, with some reluctance and even distaste on his part, in order to continue the work which Picard had planned, and no doubt hoped to carry out himself. His death took place before he realized that anything but a 'Celtic' antiquity was involved, and that his plan of campaign, if it produced any result at all, would lead to the discovery of diluvial man. Nor was Boucher de Perthes, in his earlier investigations at La Portelette, Menchecourt and the Hôpital site, in better case. So far from appreciating that his aim, as he afterwards claimed, was fossil man, it was some time before the distinction, which appears on the title-page of his capital work, between "antiquités celtiques" and "antiquités antédiluviennes" was presented to his mind. Unfortunately, when the reported occurrence of pottery and stone implements, especially of axes, which first appeared in 1841, 
convinced him, though he had not seen these finds in situ, that he was dealing with diluvial man, the heterogeneous character of the finds, which included Venetian glass, as well as knives and axes of stone which would now be termed neolithic, only provoked ridicule when submitted to expert examination. Boucher de Perthes then reverted to the idea that they belonged to a 'Celtic' civilization, though still maintaining their association with an extinct fauna. It was not until 1843 or 1844 that he saw, in situ, the first of the axes, now to be regarded as Lower Palæolithic, which confirmed his contention of the existence of diluvial man. This find from the H.opital site heralded the evidence which, notwithstanding such vagaries as a large proportion of fractured flints of non-human origin, and a collection of so-called representations of animal forms, was to win a verdict in his favour from the British commission of inquiry of 1859 .

So far as the foundation of prehistory was the outcome of anything like a scientific conception of the aims and methods of archæology, the credit belongs to Picard rather than to Boucher de Perthes ; but to the latter must be conceded a tenacity of purpose which carried through the actual investigation and won recognition in the end.

\section{The Proposed Everglades National Park, U.S.A.}

\section{By Dr. John Kunkel Small, New York Botanical Garden}

THE proposed Everglades National Park, recently authorized by the Congress of the United States, after thirty years agitation, is of importance to all who are interested in outdoor life. Its area (capable of enlargement) of two thousand square miles is less than that of several national parks in the United States and elsewhere ; but it surpasses in the abundance, variety, and activity of plant and animal life. In most large parks life is in a decline. Variety is giving way to uniformity. Erosion is tearing down mountains ; species are disappearing; plant and animal life is maintained with difficulty in increasingly artificia] conditions. Such is not the case in the Everglades. Both at the outer fringes of mangroves and far within, land is naturally and continually increasing. Life in the warm humid climate is luxuriant, active-primeval, as if species were making. Plants and animals live as they have for ages, and as they may continue to live for years to come.

The area (Fig. 1) is not technically within the tropies, but the Tropic of Cancer lies only seventyfive miles distant, and ocean currents, prevailing winds, and migratory birds have found a strictly tropical rendezvous scarcely surpassed anywhere in congenial conditions and lack of disadvantages. The area is about equally divided between land and water. The highest points of land are scarcely ten feet above tide, and the water has an average depth of but a fathom or so. Most of the area is accessible by boat in protected waters, a mode of transportation least disturbing to wild life. However, when roads and trails are desirable they can be built at little expense.

\section{Animal Life}

There are few places where marine life is so abundant and active; the greater part of it is in continuous motion and change, either anchored or free swimming. On one hand, this fact can be observed and studied in the shallow crystal-clear waters of the vast continental shelf on which the Florida Keys now stand and which fringe the mainland. These waters are teeming with life, in almost innumerable quantities and variety. A handful of mud from a bleak and lofty area like the United States Great Smoky Mountain Park will remain motionless; a handful from the Bay of Florida will be in continuous motion as a result of the included active marine life. The kinds of lowest animals-sponges, jellyfish, corals, seaanemones, moss-animals, molluscs, sea-urchins, seacucumbers, starfish and stone lilies-are legion.

Associated with these, fish of almost innumerable kinds, forms, and colours, and great range in size, abound in the waters, fresh and salt. The vast numbers of fish may be realized by the fact that the schools are often so large that they fill bays and sounds to the exclusion of a great part of the water.

Ascending in the life-scale, we find amphibians and reptiles. Frogs abound. Several kinds of large turtles are found, and the alligator and the crocodile are outstanding. Among serpents is the dangerous cotton-mouth moccasin and thelargestand mostdan. gerous American reptile, the diamond-back rattlesnake, which sometimes attains a length of nine feet. Lizards are numerous, but most of them are small.

More evident than the amphibians and reptiles are the birds. The bird life of this region is prodigious, ranging from the minute humming-bird to 